\title{
Article
}

\section{The Effect of Energy Consumption and Economic Growth on Environmental Sustainability in the GCC Countries: Does Financial Development Matter?}

\author{
Hala Baydoun $1,2,3, *(\mathbb{D})$ and Mehmet Aga ${ }^{1}$ \\ 1 Department of Accounting and Finance, Faculty of Economics and Administrative Sciences, \\ Cyprus International University, North Cyprus, Mersin 10, Haspolat 99040, Turkey; maga@ciu.edu.tr \\ 2 Department of Accounting Information Systems, School of Business, Lebanese International University, \\ Beirut, Lebanon \\ 3 Department of Banking and Finance, School of Business, Lebanese International University, Beirut, Lebanon \\ * Correspondence: hala.baydoun@liu.edu.lb
}

check for updates

Citation: Baydoun, H.; Aga, M. The Effect of Energy Consumption and Economic Growth on Environmental Sustainability in the GCC Countries: Does Financial Development Matter? Energies 2021, 14, 5897. https://doi.org/10.3390/en14185897

Academic Editor: Wing-Keung Wong

Received: 22 July 2021

Accepted: 10 September 2021

Published: 17 September 2021

Publisher's Note: MDPI stays neutral with regard to jurisdictional claims in published maps and institutional affiliations.

\begin{abstract}
Achieving environmental sustainability whilst minimizing the climate change effect has become a global endeavor. Hence, this study examined the effect of energy consumption, economic growth, financial development, and globalization on $\mathrm{CO}_{2}$ emissions in the Gulf Cooperation Council (GCC) countries. The research utilized a dataset stretching from 1995 to 2018. In a bid to investigate these associations, the study applied cross-sectional dependence (CSD), slope heterogeneity (SH), Pesaran unit root, Westerlund cointegration, cross-sectionally augmented autoregressive distributed lag (CS-ARDL), and Dumitrescu and Hurlin (DH) causality approaches. The outcomes of the CSD and $\mathrm{SH}$ tests indicated that using the first-generation techniques produces misleading results. The panel unit root analysis unveiled that the series are I (1). Furthermore, the outcomes of the cointegration test revealed a long-run association between $\mathrm{CO}_{2}$ emissions and the regressors, suggesting evidence of cointegration. The findings of the CS-ARDL showed that economic growth and energy consumption decrease environmental sustainability, while globalization improves it. The study also validated the environmental Kuznets curve (EKC) hypothesis for GCC economies. In addition, the results of the DH causality test demonstrated a feedback causality association between economic growth and $\mathrm{CO}_{2}$ emissions and between financial development and $\mathrm{CO}_{2}$ emissions. Moreover, there is a one-way causality from energy consumption and globalization to $\mathrm{CO}_{2}$ emissions in GCC economies. According to the findings, environmental pollution in GCC countries is output-driven, which means that it is determined by the amount of energy generated and consumed.
\end{abstract}

Keywords: $\mathrm{CO}_{2}$ emissions; economic growth; energy consumption; environmental sustainability; financial development; globalization

\section{Introduction}

Substantial economic expansion and industrialization have resulted in rising energy consumption and environmental deterioration, posing challenges to sustainable development [1]. In 2019, global primary energy consumption grew by 1.3\% [2]. Energy is a requirement for economic growth as well as the primary cause of environmental deterioration, and climate change is connected to the utilization of energy and greenhouse gases (GHGs) emissions [3]. Numerous environmental research studies have emphasized the need of reducing GHGs, specifically carbon dioxide $\left(\mathrm{CO}_{2}\right)$ emissions, which account for the largest chunk of GHGs [4]. Understanding the reasons for rising $\mathrm{CO}_{2}$ emissions and developing suitable mitigation plans is vital for all governments and is specifically important for the Gulf Cooperation Council (GCC) nations due to their unique features. The six Gulf countries of GCC (Kuwait, Oman, Bahrain, United Arab Emirates (UAE), Qatar, and Saudi Arabia) are rich in resources and control 19.8\% of global natural-gas holdings [2]. In fact, Saudi Arabia, UAE, and Qatar are amongst the globe's leading emitters [5]. 
Fossil fuels, an arguably abundant resource in GCC, are the foundation of these nations, which rely on earnings from fossil fuel exports to fund industrial activities, which, in turn, have a negative impact on environmental quality [6]. Although renewable energy sources account for a small portion of these economies' energy mix, they are heavily dependent on fossil fuels. In addition, the energy consumption in this region is increasing as a result of expanding populations, fast urbanization, and economic expansion, presenting a fundamental challenge to environmental sustainability [7]. These nations generate $2.4 \%$ of global GHGs, which is more than that of the European Union (EU). GCC countries are likewise anticipated to see a large upsurge in energy utilization as income grows, and the demand for luxury goods increases [7].

This research investigated the links between energy consumption (EC), economic growth (GDP), financial development (FD), globalization (GLO), and $\mathrm{CO}_{2}$ emissions $\left(\mathrm{CO}_{2}\right)$ in GCC countries. Many researchers have focused on globalization in recent years since the globalization process can impact sustainability. [8] created the globalization index, which is made up of economic, social, and political variables. It is a combination of political, social, and economic indices in the first dataset; nevertheless, subsequent research by [9] included some more sub-indices for a better understanding of this process. The association between $\mathrm{GLO}$ and $\mathrm{CO}_{2}$ has been investigated by prior studies; however, their outcomes were inconclusive. For instance, the studies of [10] for the top 10 electricity consuming countries, [11] for 23 African countries, and [12] unveiled a negative $\mathrm{GLO}-\mathrm{CO}_{2}$ connection, while the studies of [13] for BRICS, [14] for WAME countries, and [15] found a positive $\mathrm{GLO}-\mathrm{CO}_{2}$ connection.

Furthermore, financial development (FD) is a big component that can impact levels of environmental deterioration in a variety of ways. For instance, financial institutions' lending can lead to business development, which can increase energy use, land use, and waste creation. Individuals' financial demands are also supported by financial institutions, and a rise in purchasing power can increase resource consumption, resulting in more damage to the environment. On the other hand, financial institutions may encourage technical progress that reduces the utilization of energy and therefore decrease environmental damage [16]. In addition, financial institutions may play a beneficial role in supporting initiatives that may lead to technological innovation since innovation is unachievable without adequate investment in research and development. There are conflicting data on the $\mathrm{FD}-\mathrm{CO}_{2}$ relationship. For instance, the research of [17] and [18] found a negative $\mathrm{FD}-\mathrm{CO}_{2}$ connection, while the studies of [19] and [20] found a positive $\mathrm{FD}-\mathrm{CO}_{2}$ connection.

The different perspectives of these research studies suggest that globalization, energy usage, economic expansion, and financial development have varying effects on environmental deterioration. GCC countries are presently confronted with increased globalization processes as well as increased utilization of energy and GDP, posing a considerable challenge in the context of ecological quality. As a result, the current study may assist policymakers in pursuing more pragmatic planning and maximizing decision-making linked to environmental abatement in general, and particularly, in GCC nations. This study also offers several major contributions to the existing literature. Basically, it investigated the impact of energy consumption, economic growth, financial development, and globalization on $\mathrm{CO}_{2}$ emissions in GCC countries, whilst incorporating factors that are essential to the region's economic prosperity. Besides, and for the purpose of addressing the issue of CSD and heterogeneity, this study utilized an advanced panel data estimate approach, and it used a novel CS-ARDL model to solve the problems of heterogeneity and CSD of panel data, which are ignored by previous studies.

The remainder of the paper includes different sections. Section 2 is a review of the literature, and Section 3 involves the research methodology with an explanation of the empirical models, data, and methods. Section 4 presents the study results and the findings along with the discussion of these findings. Finally, Section 5 depicts the conclusion and the policy path. 


\section{Literature Review}

This section of the paper discusses in detail prior research studies conducted regarding the association between energy consumption (EC), economic growth (GDP), financial development (FD), globalization (GLO), and $\mathrm{CO}_{2}$ emissions $\left(\mathrm{CO}_{2}\right)$.

\subsection{Energy Consumption, Economic Growth, and $\mathrm{CO}_{2}$ Emissions}

In the empirical literature, it is generally acknowledged that there is a connection between EC, GDP, and $\mathrm{CO}_{2}$. Energy is needed for production, which spurs economic expansion and stimulates environmental decline. The study of [21] in Tunisia, utilizing impulse response and cointegration approaches between 1971 and 2005, unveiled a positive connection between EC and $\mathrm{CO}_{2}$. Likewise, in GCC economies, [22] assessed the EC-GDP$\mathrm{CO}_{2}$ connection by utilizing pooled mean group (PMG) and panel causality from 1980 to 2012. The empirical outcomes unveiled an insignificant connection between GDP and $\mathrm{CO}_{2}$, while EC impacted $\mathrm{CO}_{2}$ positively. Furthermore, feedback causality linkage was observed between EC and $\mathrm{CO}_{2}$. Using Toda-Yamamoto causality, [23] assessed the EC-GDP-CO connection in India by utilizing a dataset between 1971 and 2011. The outcomes of the study disclosed feedback causality linkage between $\mathrm{EC}$ and $\mathrm{CO}_{2}$. The study of [24] in 170 economies, which utilized data from 1980 to 2011 and used vector error correction model (VECM), uncovered that both EC and GDP triggered $\mathrm{CO}_{2}$. While feedback causality linkage has been demonstrated between $\mathrm{EC}$ and $\mathrm{CO}_{2}$, there was also contrasting evidence of a oneway causality from GDP to $\mathrm{CO}_{2}$. In the United States, using panel ordinary least squares (OLS) and data from 1997 to 2016, [25] found that EC and GDP impacted $\mathrm{CO}_{2}$ positively, and the study validated the environmental Kuznets curve (EKC) hypothesis. Utilizing dynamic autoregressive distributed lag (ARDL), and frequency domain causality approaches, [26] examined the EC-GDP-CO $\mathrm{CO}_{2}$ in Pakistan using data covering the period from 1972 to 2018. The outcomes unveiled that both EC and GDP contributed to environmental decline, and GDP Granger caused an increase in $\mathrm{CO}_{2}$. The positive $\mathrm{CO}_{2}$-GDP-EC association was validated by the study of [27]. Moreover, [28] assessed the $\mathrm{CO}_{2}-\mathrm{GDP}-\mathrm{EC}$ connection in Brazil using datasets from 1990 to 2018. The investigators employed the fully modified ordinary least squares (FMOLS), dynamic ordinary least squares (DOLS), and frequency domain causality approaches to demonstrate that an upsurge in EC and GDP contributed to the deterioration of the environment. Besides, the empirical analysis of the study done by [3] in South Korea, using a dataset from 1965 to 2019 and employing the ARDL, DOLS, and FMOLS approaches, showed that emissions triggered economic growth and EC mitigated GDP in South Korea. Likewise, a study conducted by [29] found that an upsurge in GDP triggered emissions levels in Australia. Moreover, the study of [30] using a dataset from 1980 to 2017 in Nigeria revealed that degradation of the environment was caused by an upsurge in both energy utilization and economic growth.

\subsection{Financial Development and $\mathrm{CO}_{2}$ Emissions}

The study of [31] on the association between FD and $\mathrm{CO}_{2}$ in G8 and D8 countries, which utilized data from 1999 to 2013 and used PMG and panel ARDL, showed that there was a positive correlation between FD and $\mathrm{CO}_{2}$ in both $\mathrm{G} 8$ and D8 economies. In addition, there was a one-way causal linkage from $\mathrm{FD}$ to $\mathrm{CO}_{2}$. Similarly, [32] looked at the connection between FD and $\mathrm{CO}_{2}$ in 184 nations from 1990 to 2017. The investigators used the generalized method of moments (GMM) to show that there was a negative connection between $\mathrm{FD}$ and $\mathrm{CO}_{2}$, suggesting that FD contributed to the sustainability of the environment in the 184 countries. On the contrary, the study of [33] in China, using data from 1980 to 2016 and ARDL, revealed a negative $\mathrm{FD}-\mathrm{CO}_{2}$ association, which demonstrated that FD contributed to the degradation of the environment. Similarly, the study of [34] on the association between FD and $\mathrm{CO}_{2}$, which was conducted on the South Asian economies and covered the years ranging from 1990 to 2014, indicated that there was a positive linkage between $\mathrm{FD}$ and $\mathrm{CO}_{2}$. In addition, FD Granger caused $\mathrm{CO}_{2}$. Likewise, [18] assessed the FD- $\mathrm{CO}_{2}$ connection in South Africa by utilizing data from 1980 to 2017. The researchers 
used ARDL, FMOLS, DOLS, and novel spectral causality approaches. The outcomes from the FMOLS and DOLS disclosed a negative connection between FD and $\mathrm{CO}_{2}$, while the causality test revealed a one-way causality from $\mathrm{FD}$ to $\mathrm{CO}_{2}$ in both the short run and the long run. Similarly, [35] scrutinized the FD- $\mathrm{CO}_{2}$ linkage in Turkey by using FMOLS and DOLS with data stretching from 1960 to 2014. The study outcomes showed a positive connection between $\mathrm{FD}$ and $\mathrm{CO}_{2}$, while the Granger causality outcome uncovered a unidirectional causality from FD to $\mathrm{CO}_{2}$ in Turkey. Moreover, using a yearly dataset spanning from 1970 to 2016, [36] assessed the financial development emissions nexus in Thailand using the novel wavelet coherence and ARDL approaches. The findings of the study uncovered that an upsurge in financial development did not have a substantial influence on the level of emissions in Thailand.

\subsection{Globalization and $\mathrm{CO}_{2}$ Emissions}

Over the years, many studies on the connection between $\mathrm{GLO}$ and $\mathrm{CO}_{2}$ have been conducted; nonetheless, there is no consensus on the influence of $\mathrm{GLO}$ on $\mathrm{CO}_{2}$. For instance, using the top 10 electricity-consuming nations, [10] assessed the GLO-CO connection using data from 1971 to 2013. The investigators applied both FMOLS and DOLS to explore the linkage between the variables, and the findings indicated that GLO negatively impacted $\mathrm{CO}_{2}$, suggesting that an upsurge in GLO improved the quality of the environment. Furthermore, there was a one-way causal linkage from GLO to $\mathrm{CO}_{2}$. Likewise, the study of [37] on the GLO- $\mathrm{CO}_{2}$ association, which was done on 31 developed and 155 developing economies between 1991 and 2018, showed a negative linkage between GLO and $\mathrm{CO}_{2}$, which implied that an upsurge in GLO mitigated the degradation of the environment. Ref. [38] examined the GLO- $\mathrm{CO}_{2}$ connection by employing the DriscollKraay estimator and data pertaining to 23 African countries from 1999 to 2017. The results disclosed a negative GLO- $\mathrm{CO}_{2}$ association. Similarly, [12] examined the GLO- $\mathrm{CO}_{2}$ association by utilizing ARDL, dual gap approach, and frequency domain causality, and the outcomes revealed that there was a negative association between $\mathrm{GLO}$ and $\mathrm{CO}_{2}$ and that GLO caused $\mathrm{CO}_{2}$. On the contrary, the research of [15] on the dynamics between GLO and $\mathrm{CO}_{2}$ in Turkey using data from 1971 to 2016 as well as Fourier autoregressive distributed lag (ADL) cointegration and Fourier causality tests found that there was a connection between GLO and $\mathrm{CO}_{2}$ Furthermore, the causality test unraveled a unidirectional causal linkage from GLO to $\mathrm{CO}_{2}$. This outcome was supported by the study of [6] in West Asia and Middle East (WAME) economies, which used data from 1990 to 2017. The study of [39] on the interrelationship between emissions and globalization using advanced time-series approaches found that an upsurge in globalization aided in mitigating emissions levels in Argentina.

Table 1 presents a synopsis of the seminal studies discussed above.

Table 1. Summary of seminal studies.

\begin{tabular}{|c|c|c|c|c|}
\hline Author(s) & Nations(s) & Time-Frame & Method(s) & Finding(s) \\
\hline \multicolumn{5}{|c|}{ Effect of EC and GDP on $\mathrm{CO}_{2}$} \\
\hline [21] & Tunisia & 1971-2005 & Cointegration, impulse response & $\begin{array}{c}\mathrm{GDP} \Leftrightarrow \mathrm{CO}_{2}(+) \\
\mathrm{EC} \Leftrightarrow \mathrm{CO}_{2}(+)\end{array}$ \\
\hline [22] & GCC economies & 1980-2012 & PMG, causality & $\begin{array}{c}\mathrm{GDP} \neq \mathrm{CO}_{2} \\
\mathrm{EC} \Leftrightarrow \mathrm{CO}_{2}(+) \\
\mathrm{EC} \Leftrightarrow \mathrm{CO}_{2}\end{array}$ \\
\hline [40] & One hundred and eighty-eight countries & 1993-2010 & PMG, causality & $\begin{array}{c}\mathrm{GDP} \Leftrightarrow \mathrm{CO}_{2}(+) \\
\mathrm{GDP} \Leftrightarrow \mathrm{CO}_{2} \\
\mathrm{EC} \Leftrightarrow \mathrm{CO}_{2}(+) \\
\mathrm{EC} \Leftrightarrow \mathrm{CO}_{2}\end{array}$ \\
\hline [23] & India & 1971-2011 & Toda-Yamamoto causality & $\begin{array}{l}\mathrm{EC} \Leftrightarrow \mathrm{CO}_{2} \\
\mathrm{GDP} \Leftrightarrow \mathrm{CO}_{2} \\
\mathrm{EC} \Leftrightarrow \mathrm{GDP}\end{array}$ \\
\hline
\end{tabular}


Table 1. Cont.

\begin{tabular}{|c|c|c|c|c|}
\hline Author(s) & Nations(s) & Time-Frame & Method(s) & Finding(s) \\
\hline [24] & One hundred and seventy countries & 1980-2011 & Panel VECM & $\begin{array}{c}\mathrm{GDP} \Leftrightarrow \mathrm{CO}_{2}(+) \\
\mathrm{GDP} \Leftrightarrow \mathrm{CO}_{2} \\
\mathrm{EC} \Leftrightarrow \mathrm{CO}_{2}(+) \\
\mathrm{EC} \Leftrightarrow \mathrm{CO}_{2}\end{array}$ \\
\hline$[20]$ & ASEAN- 5 countries & 1980-2016 & Panel causality & $\begin{array}{c}\text { In Malaysia and } \\
\text { Singapore } \\
\text { GDP } \Rightarrow \mathrm{CO}_{2} \\
\text { In Thailand } \\
\mathrm{EC} \Rightarrow \mathrm{GDP}\end{array}$ \\
\hline [25] & United States & 1997-2016 & Panel OLS & $\begin{array}{c}\mathrm{GDP} \Rightarrow \mathrm{CO}_{2}(+) \\
\mathrm{EC} \Rightarrow \mathrm{CO}_{2}(+) \\
\mathrm{GDP}^{2} \Rightarrow \mathrm{CO}_{2}(-)\end{array}$ \\
\hline [26] & Pakistan & 1972-2018 & $\begin{array}{l}\text { Dynamic ARDL, frequency } \\
\text { domain causality }\end{array}$ & $\begin{array}{c}\mathrm{GDP} \Rightarrow \mathrm{CO}_{2}(+) \\
\mathrm{EC} \Rightarrow \mathrm{CO}_{2}(+) \\
\mathrm{GDP} \Rightarrow \mathrm{CO}_{2}\end{array}$ \\
\hline$[41]$ & Thirty Chinese provinces & 2000-2017 & VECM & $\begin{array}{l}\mathrm{EC} \Rightarrow \mathrm{CO}_{2} \\
\mathrm{GDP} \Rightarrow \mathrm{CO}_{2}\end{array}$ \\
\hline [42] & Spain & 1970-2018 & $\begin{array}{l}\text { Threshold vector autoregression } \\
\text { (TVAR) }\end{array}$ & $\begin{array}{l}\mathrm{REC} \Rightarrow \mathrm{CO}_{2}(-) \\
\mathrm{GDP} \Rightarrow \mathrm{CO}_{2}(+)\end{array}$ \\
\hline \multicolumn{5}{|c|}{ Effect of FD on $\mathrm{CO}_{2}$} \\
\hline$[31]$ & G8 and D8 countries & 1999-2013 & PMG, Panel ARDL & $\begin{array}{l}\mathrm{FD} \Leftrightarrow \mathrm{CO}_{2}(+) \\
\mathrm{FD} \Leftrightarrow \mathrm{CO}_{2}\end{array}$ \\
\hline [32] & One hundred and eighty-four countries & 1990-2017 & GMM & $\mathrm{FD} \Leftrightarrow \mathrm{CO}_{2}(-)$ \\
\hline$[33]$ & China & 1995-2017 & CS-ARDL & $\mathrm{FD} \Rightarrow \mathrm{CO}_{2}(+)$ \\
\hline [43] & Bangladesh & 1980-2016 & ARDL & $\mathrm{FD} \Leftrightarrow \mathrm{CO}_{2}(-)$ \\
\hline$[34]$ & South Asian economies & 1990-2014 & FMOLS, DOLS, D-H Causality & $\begin{array}{l}\mathrm{FD} \Leftrightarrow \mathrm{CO}_{2}(+) \\
\mathrm{FD} \Rightarrow \mathrm{CO}_{2}\end{array}$ \\
\hline [18] & South Africa & 1980-2017 & ARDL, FMOLS, DOLS & $\begin{array}{l}\mathrm{FD} \Leftrightarrow \mathrm{CO}_{2}(-) \\
\mathrm{FD} \Rightarrow \mathrm{CO}_{2}\end{array}$ \\
\hline [35] & Turkey & 1960-2014 & FMOLS, DOLS & $\begin{array}{l}\mathrm{FD} \Leftrightarrow \mathrm{CO}_{2}(-) \\
\mathrm{FD} \Leftrightarrow \mathrm{CO}_{2}\end{array}$ \\
\hline \multicolumn{5}{|c|}{ Effect of GLO on $\mathrm{CO}_{2}$} \\
\hline [10] & Top ten electricity-consuming countries & 1971-2013 & FMOLS, DOLS & $\begin{array}{l}\mathrm{GLO} \Rightarrow \mathrm{CO}_{2}(-) \\
\mathrm{GLO} \Rightarrow \mathrm{CO}_{2}\end{array}$ \\
\hline [17] & $\begin{array}{l}\text { Thirty-one developed and one hundred } \\
\text { and fifty-five developing economies }\end{array}$ & 1991-2018 & GMM & $\mathrm{GLO} \Rightarrow \mathrm{CO}_{2}(-)$ \\
\hline [11] & Twenty-three African countries & 1999-2017 & Driscoll-Kraay estimator & $\begin{array}{l}\mathrm{PGLO} \Rightarrow \mathrm{CO}_{2}(-) \\
\mathrm{EGLO} \Rightarrow \mathrm{CO}_{2}(-)\end{array}$ \\
\hline$[44]$ & Sweden & 1990-2018 & Quantile-on-quantile & $\begin{array}{c}\mathrm{GLO} \Rightarrow \mathrm{CO}_{2}(-) \\
\mathrm{GLO} \Rightarrow \mathrm{CO}_{2}\end{array}$ \\
\hline [13] & BRICS & 1971-2016 & $\begin{array}{l}\text { Fourier ADL cointegration, } \\
\text { Fourier causality }\end{array}$ & $\begin{array}{c}\mathrm{GLO} \Rightarrow \mathrm{CO}_{2}(+) \\
\mathrm{GLO} \Rightarrow \mathrm{CO}_{2}\end{array}$ \\
\hline [45] & Turkey & 1971-2016 & Dual gap approach, FMOLS & $\begin{array}{c}\mathrm{GLO} \Rightarrow \mathrm{CO}_{2}(+) \\
\mathrm{GLO} \Rightarrow \mathrm{CO}_{2}\end{array}$ \\
\hline [14] & WAME countries & 1990-2017 & Panel techniques & $\begin{array}{c}\mathrm{GLO} \Rightarrow \mathrm{CO}_{2}(+) \\
\mathrm{GLO} \Rightarrow \mathrm{CO}_{2}\end{array}$ \\
\hline
\end{tabular}




\section{Research Methodology}

\subsection{Theoretical Underpinning and Model}

Economic expansion can impact $\mathrm{CO}_{2}$ in three different ways: scale, composite, and technique effects. The scale effect states that economic expansion pollutes the environment at first because it necessitates more resources and energy, resulting in greater pollution and waste [46]. The degree of pollution and the materials utilized in the production process, on the other hand, are determined by a nation's sectoral structure. As a result, the composition effect expects the structural transition of countries from the industrial to the service sector to minimize the adverse effects of economic development on the environment. Finally, the technique effect shows that when a country's affluence rises, it adopts new and sophisticated technology that boosts production whilst mitigating emissions [47].

Energy is a critical input in an economy's production process, given the enormous increase in the use of alternative energy sources, because it is the cornerstone of transportation, agricultural production, industry, and homes. Therefore, energy dependency will keep growing as the global population grows, and development and economic growth continue [48]. Urbanization and interconnected global economy will exacerbate energy consumption and reliance as a result of increased telecommunications and mobility. Increasing energy use has a negative impact on the environment, health, safety, lifestyle, and communications, as history has proven.

Furthermore, financial development may contribute to environmental quality through investing in green technology and greener energy products. Financial development, on the other side, may stimulate economic activity, resulting in higher energy consumption and $\mathrm{CO}_{2}$ emissions [18]. Scholars have disproportionately concentrated on the links between energy utilization or consumption, globalization, and their use in recent years. Theoretically, this relationship is simple; as countries become more international, their energy needs increase as well. It is commonly assumed that as globalization develops, trade barriers will decrease, resulting in increased output and income for a nation. Increases in wealth and output are connected to increases in energy usage [49]. As it is often assumed that growing globalization is related to greater levels of GDP, it is commonly assumed that GLO is a source of rising energy consumption. Based on this debate, the current study investigates the link between EC, GDP, FD, and $\mathrm{CO}_{2}$ using the following model.

This research also follows what was done by [50] through incorporating GLO into the model.

$$
\mathrm{CO}_{2 \mathrm{i}, \mathrm{t}}=\alpha_{0}+\theta_{1} \mathrm{GDP}_{\mathrm{i}, \mathrm{t}}+\theta_{2} \mathrm{EC}_{\mathrm{i}, \mathrm{t}}+\theta_{3} \mathrm{FD}_{\mathrm{i}, \mathrm{t}}+\theta_{4} \mathrm{GLO}_{\mathrm{i}, \mathrm{t}}+\varepsilon_{\mathrm{i}, \mathrm{t}}
$$

In the above equation, i illustrates the cross-sections, i.e., GCC countries. The period of time (1995-2018) is depicted by $t$. The intercept term is denoted by $\alpha$. Moreover, $\varepsilon$ and $\theta / \mathrm{s}$ stand for parameters and error terms, respectively. Carbon dioxide $\left(\mathrm{CO}_{2}\right)$ emissions are illustrated by $\mathrm{CO}_{2}$ which is calculated as per capita emissions. Economic growth is measured as GDP per capita (constant USD \$2010), which is utilized in measuring the degradation of the environment. The energy utilization or consumption is represented by EC, and it is calculated as energy use per capita (Kwh). Financial development (FD) is measured as domestic credit to the private sector, and it is depicted by FD. Finally, globalization (GLO) is measured as an index based on foreign direct investment (FDI), trade, and portfolio investment. In this study, both $\mathrm{EC}$ and $\mathrm{CO}_{2}$ are obtained from the database of British petroleum (BP). Furthermore, GDP and FD are gathered from the World Bank database of world development indicators (WDI). Lastly, GLO is gathered from [9].

In terms of the anticipated signs of the indicators' coefficients, it is generally believed that increasing output leads to environmental deterioration via growing resource and energy usage. The continuous growth of GCC economies presents a severe danger to the environment due to unsustainable development practices. Thus, it is predicted that the relationship between GDP and $\mathrm{CO}_{2}$ is positive $\left(\theta_{1}=\frac{\delta \mathrm{CO}_{2}}{\delta \mathrm{GDP}}>0\right)$. A large proportion of energy utilization in GCC countries comes from nonrenewable energy sources. Therefore, 
a positive connection is anticipated between EC and $\mathrm{CO}_{2}\left(\theta_{2}=\frac{\delta \mathrm{CO}_{2}}{\delta \mathrm{EC}}>0\right)$. Besides, a negative association is expected to appear between $\mathrm{FD}$ and $\mathrm{CO}_{2}\left(\theta_{3}=\frac{\delta \mathrm{CO}_{2}}{\delta \mathrm{FD}}<0\right)$; otherwise, it is deemed positive when it is not eco-friendly $\left(\theta_{3}=\frac{\delta \mathrm{CO}_{2}}{\delta \mathrm{FD}}>0\right)$. Lastly, GLO is included in the empirical model of $\mathrm{CO}_{2}$. Globalization has boosted competitiveness by expanding the flow of products and services, posing a serious danger on the environment. As a result, GLO is anticipated to positively impact $\mathrm{CO}_{2}\left(\theta_{4}=\frac{\delta \mathrm{CO}_{2}}{\delta \mathrm{GLO}}>0\right)$; otherwise, it is deemed negative when it is eco-friendly $\left(\theta_{4}=\frac{\delta \mathrm{CO}_{2}}{\delta \mathrm{GLO}}<0\right)$.

\subsection{Data}

The research used panel data for GCC nations from 1995 to 2018 to assess the dynamic connection between $\mathrm{CO}_{2}$ and the regressors. The variables employed in this empirical analysis are $\mathrm{CO}_{2}$ emissions $\left(\mathrm{CO}_{2}\right)$, economic growth (GDP), energy consumption (EC), financial development (FD), and globalization (GLO). Table 2 comprises the variables, the signs, the measurements, and the data sources.

Table 2. Variables, signs, measurements, and data sources.

\begin{tabular}{cccc}
\hline Variable & Sign & Measurement & Data Source \\
\hline $\mathrm{CO}_{2}$ emissions & $\mathrm{CO}_{2}$ & Per capita emissions & BP \\
\hline Economic growth & GDP & Per Capita (constant USD \$2,010) & WDI \\
\hline Energy consumption & EC & Per capita energy use & BP \\
\hline Financial development & FD & Domestic credit to the private sector & WDI \\
\hline Globalization & GLO & $\begin{array}{c}\text { Index based on FDI, trade, and } \\
\text { portfolio investment }\end{array}$ & {$[9]$} \\
\hline
\end{tabular}

\subsection{Estimation Approaches}

\subsubsection{Cross-Sectional Dependence (CSD) Test}

This study commenced by examining cross-sectional dependence (CSD) because the nations are linked via numerous economic, social, and cultural networks that may produce spillover effects. Consequently, this research utilized both the Pesaran Scaled LM and [51] $\mathrm{CD}$ tests to ascertain the cross-sectional dependence. The CSD test equation is stipulated as follows:

$$
\operatorname{CSD}=\sqrt{\frac{2 \mathrm{~T}}{\mathrm{~N}(\mathrm{~N}-1)}}\left(\sum_{\mathrm{i}=1}^{\mathrm{N}-1} \sum_{\mathrm{j}=\mathrm{i}+1}^{\mathrm{N}} \hat{\rho}_{\mathrm{ij}}\right)
$$

In this equation, the pairwise correlation is illustrated by $\hat{\rho}_{\mathrm{ij}}$.

\subsubsection{Slope Heterogeneity (SH) Test}

The next phase assessed the existence of slope heterogeneity amongst the crosssectional units. The issue of heterogeneity must be determined because, due to differences in the developing nations' economic and demographic structure, there is a possibility of slope heterogeneity, which can potentially affect the consistency of panel estimators. For this reason, this study utilized the slope heterogeneity test. The [52] test is illustrated below:

$$
\begin{gathered}
\widetilde{\Delta}_{\mathrm{SH}}=(\mathrm{N})^{\frac{1}{2}}(2 \mathrm{k})^{-\frac{1}{2}}\left(\frac{1}{\mathrm{~N}} \widetilde{\mathrm{S}}-\mathrm{k}\right) \\
\widetilde{\Delta}_{\mathrm{ASH}}=(\mathrm{N})^{\frac{1}{2}}\left(\frac{2 \mathrm{k}(\mathrm{T}-\mathrm{k}-1)}{\mathrm{T}+1}\right)^{-\frac{1}{2}}\left(\frac{1}{\mathrm{~N}} \widetilde{\mathrm{S}}-2 \mathrm{k}\right)
\end{gathered}
$$


In the above equation, $\widetilde{\Delta}_{\mathrm{SH}}$ and $\widetilde{\Delta}_{\mathrm{ASH}}$ stand for delta tilde and adjusted delta tilde, respectively.

\subsubsection{Stationarity Test}

Understanding the stationarity characteristics of a series is critical in empirical analysis. To capture the stationarity features of the series under consideration, we used both crosssectionally augmented Dicky-Fuller (CADF) the cross-sectionally augmented panel unit root test (CIPS). These methods work well, especially when the slope is heterogeneous, and there is CSD. The equations for these tests are as follows:

$$
\Delta \mathrm{Y}_{\mathrm{i}, \mathrm{t}}=\gamma_{\mathrm{i}}+\gamma_{\mathrm{i}} \mathrm{Y}_{\mathrm{i}, \mathrm{t}-1}+\gamma_{\mathrm{i}} \overline{\mathrm{X}}_{\mathrm{t}-1}+\sum_{\mathrm{l}=0}^{\mathrm{p}} \gamma_{\mathrm{il}} \Delta \overline{\mathrm{Y}_{\mathrm{t}-1}}+\sum_{\mathrm{l}=1}^{\mathrm{p}} \gamma_{\mathrm{il}} \Delta \mathrm{Y}_{\mathrm{i}, \mathrm{t}-1}+\varepsilon_{\mathrm{it}}
$$

In this equation, the averages of the first differences and the lagged indicators are illustrated by $\Delta \bar{Y}_{t-1}$ and $\bar{Y}_{t-1}$, respectively. Moreover, by taking the average of each CADF, the CIPS is obtained as illustrated in the following equation:

$$
\widehat{\mathrm{CIPS}}=\frac{1}{\mathrm{~N}} \sum_{\mathrm{i}=1}^{\mathrm{n}} \mathrm{CADF}_{\mathrm{i}}
$$

\subsubsection{Cointegration Test}

It is critical to capture the long-term relationship between the variables studied. As a result, the cointegration test of [53] was used in this study to capture the long-run relationship between $\mathrm{CO}_{2}$ and the regressors. Unlike the traditional cointegration tests (e.g., Kao and Pedroni), this test offers impartial outcomes in the presence of CSD and heterogeneity. The cointegration test is presented as follows:

$$
\alpha \mathrm{i}(\mathrm{L}) \Delta \mathrm{y}_{\mathrm{it}}=\mathrm{y} 2_{\mathrm{it}}+\beta_{\mathrm{i}}\left(\mathrm{y}_{\mathrm{it}}-1-\hat{\alpha}_{\mathrm{i}} \mathrm{x}_{\mathrm{it}}\right)+\lambda_{\mathrm{i}}(\mathrm{L}) \mathrm{v}_{\mathrm{it}}+\eta_{\mathrm{i}}
$$

where $\delta_{1 \mathrm{i}}=\beta_{\mathrm{i}}(1) \hat{\vartheta}_{21}-\beta_{\mathrm{i}} \lambda_{1 \mathrm{i}}+\beta_{\mathrm{i}} \hat{\vartheta} 2_{\mathrm{i}}$ and $\mathrm{y} 2_{\mathrm{i}}=-\beta_{\mathrm{i}} \lambda 2_{\mathrm{i}}$

The Westerlund cointegration statistics are presented as follows:

$$
\begin{gathered}
\mathrm{G}_{\mathrm{t}}=\frac{1}{\mathrm{~N}} \sum_{\mathrm{i}-1}^{\mathrm{N}} \frac{\hat{\alpha}_{\mathrm{i}}}{\operatorname{SE}\left(\hat{\alpha}_{\mathrm{i}}\right)} \\
\mathrm{G}_{\alpha}=\frac{1}{\mathrm{~N}} \sum_{\mathrm{i}-1}^{\mathrm{N}} \frac{\mathrm{T}^{\alpha_{\mathrm{i}}}}{\hat{\alpha}_{\mathrm{i}}(1)} \\
\mathrm{P}_{\mathrm{t}}=\frac{\hat{\alpha}}{\operatorname{SE}(\hat{\alpha})} \\
\mathrm{P}_{\alpha}=\mathrm{T} \tilde{\alpha}
\end{gathered}
$$

In the above equation, $G_{t}$ and $G_{\alpha}$ stand for group means statistics, while $P_{t}$ and $P_{\alpha}$ pertain to panel statistics.

\subsubsection{Cross-Sectionally Augmented Autoregressive Distributed Lag (CS-ARDL)}

The CS-ARDL test, developed by [54], was used in this work for both long-run and short-run estimates. This test is more reliable and efficient than other approaches such as mean group (MG), pooled mean group (PMG), augmented mean group (AMG), and common correlated effect mean group (CCMG). The problems of homogeneity slope coefficients, CSD, non-stationarity, unobserved common variables, and endogeneity are all addressed by this technique. This is due to the fact that ignoring unobserved common 
variables will result in incorrect estimation results, as stated by Wang et al. (2021). The equation below depicts the CS-ARDL:

$$
Y_{i t}=\sum_{i=1}^{p y} \pi_{i t} Y_{i, t}+\sum_{i=0}^{p z} \theta_{i 1}^{\iota} Z_{i, t-1}+\sum_{i=0}^{p T} \phi_{i 1}^{\iota} Z_{i, t-1}+e_{i t}
$$

In this equation, $\mathrm{X}_{\mathrm{t}-1}^{-}=\left(\mathrm{Y}_{\mathrm{t}-1^{-}}^{-}, \mathrm{Z}_{\mathrm{t}-1^{\mathrm{l}}}^{-}\right) \mathrm{l}, \overline{\mathrm{Y}_{\mathrm{t}}}$ and $\overline{\mathrm{Z}_{\mathrm{t}}}$ illustrate average cross-sections. Moreover, $X_{t-1}^{-}$illustrates the averages of both dependent and regressors:

$$
\begin{gathered}
\hat{\vartheta}_{\mathrm{CS}-\mathrm{ARDL}, \mathrm{i}}=\frac{\sum_{\mathrm{i}=0}^{\mathrm{pz}} \hat{\theta}_{\mathrm{iI}}^{\mathrm{l}}}{1-\sum_{\mathrm{I}=1}^{\mathrm{py}} \hat{\pi}_{\mathrm{iI}}} \\
\hat{\vartheta}_{\text {mean group }(\mathrm{MG})}=\frac{1}{\mathrm{~N}} \sum_{\mathrm{i}=1}^{\mathrm{N}} \hat{\vartheta}_{\mathrm{i}}
\end{gathered}
$$

\subsubsection{Dumitrescu and Hurlin (DH) Causality}

The study used a causality test established by Dumitrescu and Hurlin (2012), to evaluate the causative relationship between $\mathrm{CO}_{2}$ emissions and each of $\mathrm{EC}, \mathrm{GDP}, \mathrm{FD}$, and GLO. This test is appropriate if $\mathrm{T}$ is larger than or equal to $\mathrm{N}$. This approach is also beneficial for a balanced and diverse panel data collection. This approach can also be used to deal with cross-sectional dependency. Equation (15) depicts the Dumitrescu and Hurlin causality test as follows:

$$
z_{i, t}=\alpha_{i}+\sum_{j=1}^{p} \beta_{i}^{j} z_{i, t-j}+\sum_{j=1}^{p} \gamma_{i}^{j} T_{i, t-j}
$$

In the above equation, the lag length is illustrated by $\mathrm{j}$, and the autoregressive parameters are depicted by $\beta^{j}(j)$. The alternative and null hypotheses postulate causal association and no causal association, respectively.

\section{Findings and Discussion}

\subsection{Findings}

The empirical analyses of this study are depicted in this section. First, we conducted a CSD test on the variables included in the study. The outcome of the CSD test is presented in Table 3. The findings unveiled that all the series have the issue of CSD. The outcomes demonstrated that we failed to reject the alternative hypothesis. The importance of the CSD is derived from the fact that in today's globalized world, nations are intertwined. This means that any change in one GCC nation's fundamental variable might affect other GCC nations. As a result of spillover effects, the variables are cross-sectionally dependent. Moreover, Table 4 shows that GCC nations have different levels of technological advancement and growth. As a consequence, the findings confirmed the occurrence of heterogeneity slope coefficients. Furthermore, we assessed the stationarity characteristics of the series which are depicted in Table 5, and the outcomes revealed that the series are I (1) variables.

Table 3. Cross-sectional dependence (CSD) outcomes.

\begin{tabular}{cccccc}
\hline & $\mathrm{CO}_{2}$ & GDP & EC & FD & GLO \\
\hline Breusch-Pagan LM & $227.24^{*}$ & $99.257^{*}$ & $162.43^{*}$ & $227.24^{*}$ & $410.54^{*}$ \\
\hline Pesaran scaled LM & $38.749^{*}$ & $15.383^{*}$ & $26.918^{*}$ & $38.749 *$ & $72.216^{*}$ \\
\hline Bias-corrected scaled LM & $38.646^{*}$ & $15.279 *$ & $26.815^{*}$ & $38.646^{*}$ & $72.113^{*}$ \\
\hline Pesaran CD & $14.512 *$ & $4.3758^{*}$ & $-1.7779 * *$ & $14.512 *$ & $20.261 *$ \\
\hline
\end{tabular}

Note: ${ }^{*}$ and ${ }^{* * *}$ depict $p<1 \%$ and $p<10 \%$, respectively. 
Table 4. Slope heterogeneity (SH) outcomes.

\begin{tabular}{ccc}
\hline & Test Value & $p$-Value \\
\hline Delta tilde & 4.352 & $0.000 *$ \\
\hline Delta tilde adjusted & 4.972 & $0.000 *$ \\
\hline Note: ${ }^{*}$ depicts $p<1 \%$. & &
\end{tabular}

Table 5. Cross-sectionally augmented panel unit root test (CIPS) outcomes.

\begin{tabular}{ccc}
\hline & Level & First Difference \\
\hline $\mathrm{CO}_{2}$ & -2.103 & $-5.867^{*}$ \\
\hline GDP & -1.828 & $-4.474^{*}$ \\
\hline EC & -1.722 & $-5.234^{*}$ \\
\hline FD & -1.741 & $-3.527^{*}$ \\
\hline GLO & -2.586 & $-5.300 *$ \\
\hline
\end{tabular}

Note: * depicts $p<1 \%$.

It is crucial to capture the long-run connections between $\mathrm{CO}_{2}$ and each of EC, GDP, FD, and GLO in GCC economies. In doing so, we applied the cointegration test of [53], and the outcomes are shown in Table 6 . Those outcomes unveiled the presence of a long-run association between $\mathrm{CO}_{2}$ and each of EC, GDP, FD, and GLO. Furthermore, as a robustness check, we employed the Pedroni and Kao cointegration tests, and the results of these tests are presented in Table 7 . Those results provided evidence of a long-run connection between $\mathrm{CO}_{2}$ and each of EC, GDP, FD, and GLO. Thus, the results of the Pedroni and Kao cointegration tests validate the [53] cointegration test.

Table 6. Cointegration test outcomes.

\begin{tabular}{cccc}
\hline Statistic & Value & Z-Value & $p$-Value \\
\hline $\mathrm{Gt}$ & $-3.275^{*}$ & -3.087 & 0.001 \\
\hline $\mathrm{Ga}$ & -6.022 & 1.328 & 0.908 \\
\hline $\mathrm{Pt}$ & $-6.423^{* *}$ & -1.944 & 0.026 \\
\hline $\mathrm{Pa}$ & -6.257 & -0.048 & 0.481 \\
\hline
\end{tabular}

Note: ${ }^{*}$ and ${ }^{* *}$ depict $p<1 \%$ and $p<5 \%$, respectively.

After we affirmed the long-run interrelationship between $\mathrm{CO}_{2}$ and the regressors, we proceeded to the estimation of the long-run and the short-run connection between $\mathrm{CO}_{2}$ emissions and the regressors after the long-run cointegration between $\mathrm{CO}_{2}$ and each of EC, GDP, FD, and GLO has been established. In doing so, we applied the CS-ARDL to capture both the short-run and the long-run connections between $\mathrm{CO}_{2}$ and the regressors. The outcomes of the long-run CS-ARDL are presented in Table 8. They revealed the following: the influence of $\mathrm{CO}_{2}$ on GDP growth is positive and significant, suggesting that a $1.829 \%$ upsurge in $\mathrm{CO}_{2}$ is attributed to a $1 \%$ upsurge in GDP in GCC economies when other indicators are kept constant. Besides, we also affirmed the EKC hypothesis since the coefficient of GDPSQ is negative (-0.127) and statistically significant. Furthermore, the connection between $\mathrm{CO}_{2}$ and energy consumption is positive and significant which implies that keeping other factors constant, a $1 \%$ upsurge in utilization of energy triggers $\mathrm{CO}_{2}$ by $0.028 \%$. Moreover, the FD- $\mathrm{CO}_{2}$ association is positive and insignificant. Lastly, the GLO- $\mathrm{CO}_{2}$ connection is negative and significant illustrating that a $0.922 \%$ decrease in $\mathrm{CO}_{2}$ is linked with a $1 \%$ upsurge in globalization keeping other factors constant. 
Table 7. Kao and Pedroni outcomes.

\begin{tabular}{|c|c|c|c|c|}
\hline \multicolumn{5}{|c|}{ Panel A: Kao } \\
\hline & T-Stat & Prob & & \\
\hline ADF & $-4.4890 *$ & 0.0000 & & \\
\hline $\begin{array}{l}\text { Residual- } \\
\text { variance }\end{array}$ & 0.0018 & & & \\
\hline HAC variance & 0.0014 & & & \\
\hline \multicolumn{5}{|c|}{ Panel B: Pedroni } \\
\hline & & \multicolumn{3}{|c|}{ Weighted } \\
\hline & Stat & Prob & Stat & Prob \\
\hline Panel v-stat & 1.1438 & 0.1263 & 1.1543 & 0.1242 \\
\hline Panel rho-stat & 0.2267 & 0.5897 & 0.2645 & 0.6043 \\
\hline Panel PP-stat & $-2.3354 *$ & 0.0098 & $-2.0974^{* *}$ & 0.0180 \\
\hline Panel ADF-stat & $-2.3855 *$ & 0.0085 & $-2.1508^{* *}$ & 0.0157 \\
\hline Group rho-stat & $1.1387 *$ & 0.8726 & & \\
\hline Group PP-stat & $-3.1699 *$ & 0.0008 & & \\
\hline Group ADF-stat & $-4.5722 *$ & 0.0000 & & \\
\hline
\end{tabular}

Table 8. Cross-sectionally augmented autoregressive distributed lag (CS-ARDL) outcomes.

\begin{tabular}{ccccc}
\hline \multicolumn{5}{c}{ Panel A: Short-Run Results } \\
\hline Regressors & Coefficient & StdErr. & Z-Stat. & $p$-Value \\
\hline ECM $(-1)$ & $-0.801^{*}$ & 0.2901 & -4.017 & 0.002 \\
\hline GDP & $1.080^{*}$ & 0.362 & 4.669 & 0.000 \\
\hline GDPSQ & $-0.053^{* *}$ & 0.018 & -1.903 & 0.014 \\
\hline EC & $0.038^{* * *}$ & 0.013 & 1.886 & 0.064 \\
\hline FD & 1.170 & 0.609 & 0.727 & 0.468 \\
\hline GLO & $-1.835^{*}$ & 0.049 & -3.929 & 0.000 \\
\hline Panel B: Long-Run Results & & \\
\hline GDP & Coefficient & StdErr. & Z-Stat. & 0.062 \\
\hline GDPSQ & $1.829^{* * *}$ & 0.030 & 1.886 & 0.006 \\
\hline EC & $-0.127^{*}$ & 0.045 & -2.784 & 0.000 \\
\hline FD & $0.028^{*}$ & 0.004 & 6.252 & 0.141 \\
\hline GLO & -1.679 & 0.133 & -1.480 & 0.000 \\
\hline
\end{tabular}

Note: ${ }^{*}, *$, and ${ }^{* * *}$ depict $p<1 \%, p<5 \%$, and $p<10 \%$, respectively.

After confirming the association between $\mathrm{CO}_{2}$ and the regressors (EC, GDP, FD, and GLO) in the long run, we also estimated the short-run associations which are represented in Table 8. In the short run, the CS-ARDL showed similar results to those seen in the long-run outcomes. In the short run, the influence of GDP and $\mathrm{EC}$ on $\mathrm{CO}_{2}$ is positive, while GLO impacts $\mathrm{CO}_{2}$ negatively. As anticipated, the error correction model (ECM) is negative $(-0.801)$, which illustrates that corrections made in past periods can be rectified in succeeding periods.

The present study takes a step further by assessing the causal connection between $\mathrm{CO}_{2}$ and each of EC, GDP, and GLO in GCC countries. The outcomes of the causal association between $\mathrm{CO}_{2}$ and the regressors are presented in Table 9. The outcomes from the D-H 
causality test uncovered a one-way causal linkage from the utilization of energy to $\mathrm{CO}_{2}$. This demonstrates that $\mathrm{EC}$ can predict $\mathrm{CO}_{2}$. Moreover, there is bidirectional causality between $\mathrm{FD}$ and $\mathrm{CO}_{2}$, which implies that $\mathrm{FD}$ can predict $\mathrm{CO}_{2}$ and vice-versa. Furthermore, there is a feedback causality association between GDP and $\mathrm{CO}_{2}$, which implies that both GDP and $\mathrm{CO}_{2}$ can predict each other. Lastly, there is a unidirectional causal linkage from GLO to $\mathrm{CO}_{2}$, which indicates that GLO can predict $\mathrm{CO}_{2}$ emissions. Figure 1 illustrates the graphical findings of the empirical analysis.

Table 9. Dumitrescu and Hurlin (DH) causality outcomes.

\begin{tabular}{|c|c|c|c|c|}
\hline Direction of Causality & W-Stat. & Zbar-Stat. & Prob. & Decision \\
\hline $\mathrm{EC} \rightarrow \mathrm{CO}_{2}$ & $2.78598^{* *}$ & 2.54193 & 0.0110 & \multirow{2}{*}{$\begin{array}{l}\text { One-way } \\
\text { causality }\end{array}$} \\
\hline $\mathrm{CO}_{2} \rightarrow \mathrm{EC}$ & 0.81241 & -0.40790 & 0.6833 & \\
\hline $\mathrm{FD} \rightarrow \mathrm{CO}_{2}$ & $6.68909 *$ & 8.31375 & 0.0000 & \multirow{2}{*}{$\begin{array}{l}\text { Feedback } \\
\text { causality }\end{array}$} \\
\hline $\mathrm{CO}_{2} \rightarrow \mathrm{FD}$ & $4.03315^{*}$ & 4.37064 & 0.0000 & \\
\hline $\mathrm{GDP} \rightarrow \mathrm{CO}_{2}$ & $4.00496 *$ & 4.38192 & 0.0000 & \multirow{2}{*}{$\begin{array}{l}\text { Feedback } \\
\text { causality }\end{array}$} \\
\hline $\mathrm{CO}_{2} \rightarrow \mathrm{GDP}$ & $7.64135^{*}$ & 9.83586 & 0.0000 & \\
\hline $\mathrm{GLO} \rightarrow \mathrm{CO}_{2}$ & $7.36713^{*}$ & 9.37155 & 0.0000 & \multirow{2}{*}{$\begin{array}{l}\text { One-way } \\
\text { causality }\end{array}$} \\
\hline $\mathrm{CO}_{2} \rightarrow \mathrm{GLO}$ & 0.67537 & -0.47251 & 0.5953 & \\
\hline
\end{tabular}

Note: ${ }^{*}$ and ${ }^{* *}$ depict $p<1 \%$ and $p<5 \%$, respectively.

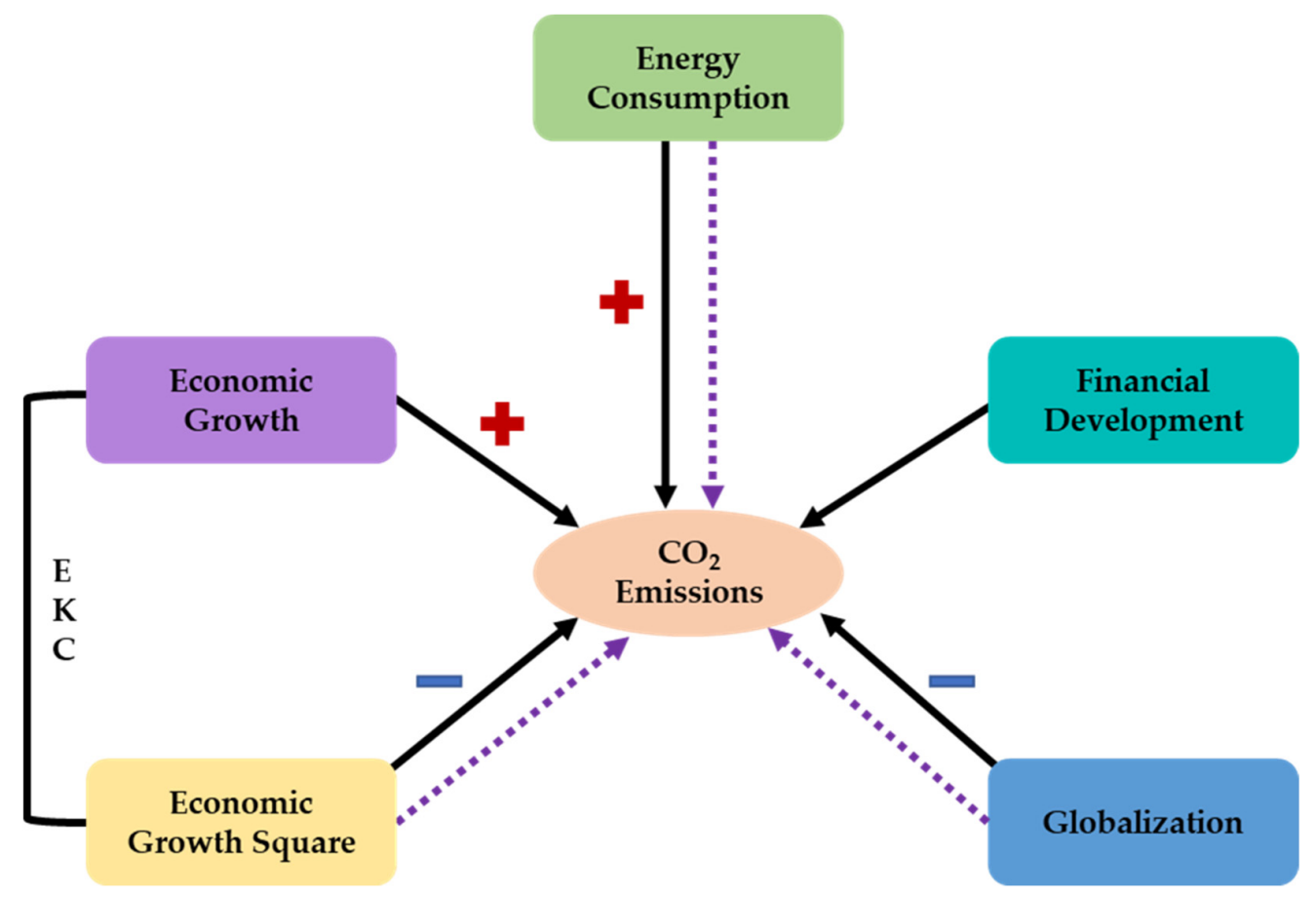

Figure 1. Graphical findings.

\subsection{Discussion of Findings}

This section of the empirical analysis discusses in detail the findings mentioned above. With the aim of investigating the effect of energy consumption (EC), economic growth (GDP), financial development (FD), and globalization (GLO) on $\mathrm{CO}_{2}$ emissions $\left(\mathrm{CO}_{2}\right)$ in GCC countries, we applied both the CS-ARDL and panel causality techniques. The outcomes from the CS-ARDL revealed that economic growth causes an upsurge in the degradation of the environment in GCC economies. This simply means that GCC nations are majorly pro-growth economies. Thus, they favor economic expansion at the expense of the quality of the environment. As a result, economic growth stimulates the consumption of 
energy in GCC countries, which leads to a rise in environmental deterioration. This further implies that, in pursuit of rapid economic expansion, GCC economies' environmental quality has deteriorated. The study also affirmed the EKC hypothesis, which indicates that GCC economies are on the right path towards environmental sustainability. This outcome is consistent with the study of [55] who found that an upsurge in $\mathrm{CO}_{2}$ in Malaysia is attributed to an upsurge in economic expansion. Moreover, the studies of [28] for Brazil, [16] for highly decentralized economies, and [39] for Argentina comply with this finding by establishing a positive interrelationship between economic growth and $\mathrm{CO}_{2}$ emissions.

Furthermore, we found that there is a positive interrelationship between energy consumption and $\mathrm{CO}_{2}$ emissions in both the long run and the short run. This outcome is not surprising given the fact that energy consumption is necessary for economic growth which also triggers the degradation of the environment. Thus, utilization of nonrenewable energy triggers economic expansion which, in turn, mitigates a negative impact on the environment in GCC nations. This finding concurs with the study of [12] for Mexico, which demonstrated that there is a positive interconnection between emissions and energy use. The study of [56] for selected Latin American countries also complies with this finding. Additionally, our finding is consistent with the studies of [45] for India and [57] for Chile.

Moreover, the short-term and the long-term association between financial development and $\mathrm{CO}_{2}$ emissions is positive and insignificant. This finding is unsurprising given that financial development may not mitigate environmental degradation in emerging countries such as GCC countries, where the structural transition of the financial sector is still in its infant phase. This outcome concurs with the works of [12] for Mexico and [14] for emerging nations; however, it contradicts the outcomes of [18] for South Africa and [58] for Malaysia who established a negative association between FD and $\mathrm{CO}_{2}$.

We also found that there is a negative interrelationship between globalization and $\mathrm{CO}_{2}$ emissions, which implies that globalization plays a vital role in abating emissions levels in GCC economies. One possible reason for the negative connection between globalization and $\mathrm{CO}_{2}$ is that globalization through trade also enables technical advancement and leads to an increase in economic activity. According to the research of [59] on Andean nations (e.g., Colombia, Peru, Bolivia, and Ecuador), trade openness stimulates industrialization via the capacitive effect, scale effect, comparative advantages effect, and technique effect. It stimulates investment, which, in turn, affects economic activity, energy consumption, and, ultimately, environmental degradation. This outcome conforms with the studies of [37] for Japan, [60] for APEC economies, and [61] for the 15 highest emitting countries. Nonetheless, this outcome contradicts the findings of [62] for South Africa, [63] for Australia, and [15] who found that there is a positive association between globalization and $\mathrm{CO}_{2}$ emissions.

To capture the causal influence of economic growth, financial development, and globalization on $\mathrm{CO}_{2}$ in GCC economies, we applied the panel causality approach. The outcomes of this test revealed that energy utilization or consumption, economic growth, and globalization play a vital role in predicting the level of emissions in GCC countries. This outcome infers that any policy directed towards energy consumption, economic growth, and globalization will have a substantial influence on emissions of $\mathrm{CO}_{2}$ in GCC nations. The above findings have significant policy consequences for GCC countries regarding $\mathrm{CO}_{2}$ emissions.

\section{Conclusions and Policy Path}

This research study assessed the effect of energy consumption, economic growth, financial development, and globalization on $\mathrm{CO}_{2}$ emissions in GCC nations by utilizing a dataset stretching between 1995 and 2018. To investigate these connections, the study used cross-sectional dependence, slope heterogeneity, Pesaran unit root, Westerlund cointegration, cross-sectionally augmented autoregressive distributed lag, and Dumitrescu and Hurlin causality approaches. The outcomes of both CSD and SH tests revealed that using the first-generation techniques produces incorrect results. Thus, this study relied on second-generation approaches. Besides, the findings of the panel unit root test unveiled 
that the series are I (1). Furthermore, the results of the cointegration test unveiled a longrun association between $\mathrm{CO}_{2}$ and the regressors, suggesting evidence of cointegration. The outcomes of the CS-ARDL showed that economic growth and energy consumption decrease the sustainability of the environment, while globalization improves it. Moreover, the outcomes of the $\mathrm{DH}$ causality test demonstrated feedback causality association between GDP and $\mathrm{CO}_{2}$ and between FD and $\mathrm{CO}_{2}$. In addition, there is a one-way causality from energy use and globalization to $\mathrm{CO}_{2}$ emissions in GCC economies.

To achieve environmental quality, the current energy regulations must be changed to support green energy sources and other energy-efficient technologies. This research showed that there is a negative link between globalization and $\mathrm{CO}_{2}$ emissions. As a result, GCC economies should implement the following policy suggestions: Openness to new markets and business partners will aid in the improvement of environmental quality. Environmental deterioration may be reduced by establishing possibilities and flexibility for imports of renewable technology and clear environmental regulations and rules. Policymakers in GCC economies may also strengthen relationships with their foreign commercial partners in order to relieve poverty, create new job opportunities, and increase exports and imports. If these steps are adopted, global trading partners will recognize the value of doing business with GCC countries. Interestingly, financial development has little effect on $\mathrm{CO}_{2}$ emissions in GCC economies. Financial development may not enhance environmental protection in developing economies, such as GCC nations and other developing countries where the financial sector is still in the early stages of structural transformation. This proposes the need to broaden the financial basis, specifically in terms of public-private partnerships (PPPs) in clean and renewable energy usage to promote clean energy (Sustainable Development Goal-7/SDG-7) and clean environment (SDG-13). In addition, the increase in $\mathrm{CO}_{2}$ emissions, due to economic expansion, reduces environmental sustainability. This implies that policymakers in GCC economies should exercise caution when enacting policies that promote economic expansion at the price of environmental deterioration. Consequently, there is a need to create effective energy-conserving policies that strike a balance between GCC countries' energy mix, environmental plans, and macroeconomic aims. This will promote long-term economic growth without jeopardizing energy efficiency; instead, a paradigm shift to renewables such as thermal, hydro, wind, and solar energy may be undertaken.

Though this research assessed the association between $\mathrm{CO}_{2}$ emissions and each of energy consumption, economic growth, financial development, and globalization, further studies should be conducted by using an asymmetric approach and including additional variables. Moreover, other metrics of environmental degradation should be considered in future studies.

Author Contributions: Conceptualization, H.B. and M.A.; methodology, H.B.; software, H.B.; validation, H.B.; formal analysis, H.B.; investigation, H.B.; resources, H.B. and M.A.; data curation, H.B.; writing-original draft preparation, H.B.; writing-review and editing, H.B. and M.A.; visualization, H.B.; supervision, M.A.; project administration, H.B. and M.A.; funding acquisition, H.B. Both authors have read and agreed to the published version of the manuscript.

Funding: The APC was funded by a research grant from the Lebanese International University (LIU).

Institutional Review Board Statement: Not Applicable.

Informed Consent Statement: Not applicable.

Data Availability Statement: Data is readily available at the request from the corresponding author.

Conflicts of Interest: The authors declare no conflict of interest. 


\section{References}

1. Shan, S.; Ahmad, M.; Tan, Z.; Adebayo, T.S.; Man Li, R.Y.; Kirikkaleli, D. The role of energy prices and non-linear fiscal decentralization in limiting carbon emissions: Tracking environmental sustainability. Energy 2021, 234, 121243. [CrossRef]

2. BP. British Petroleum. 2021. Available online: https://www.bp.com/en/global/corporate/careers/professionals/locations/ sweden.html\#/ (accessed on 25 January 2021).

3. Awosusi, A.A.; Kirikkaleli, D.; Akinsola, G.D.; Adebayo, T.S.; Mwamba, M.N. Can $\mathrm{CO}_{2}$ emissions and energy consumption determine the economic performance of South Korea? A time series analysis. Environ. Sci. Pollut. Res. 2021, 28, 38969-38984.

4. Orhan, A.; Adebayo, T.S.; Genç, S.Y.; Kirikkaleli, D. Investigating the Linkage between Economic Growth and Environmental Sustainability in India: Do Agriculture and Trade Openness Matter? Sustainability 2021, 13, 4753. [CrossRef]

5. Luciani, G. Business Politics in the Middle East; Hurst Publishers: London, UK, 2013.

6. Kihombo, S.; Vaseer, A.I.; Ahmed, Z.; Chen, S.; Kirikkaleli, D.; Adebayo, T.S. Is there a tradeoff between financial globalization, economic growth, and environmental sustainability? An advanced panel analysis. Environ. Sci. Pollut. Res. 2021. [CrossRef] [PubMed]

7. Zmami, M.; Ben-Salha, O. An empirical analysis of the determinants of $\mathrm{CO}_{2}$ emissions in GCC countries. Int. J. Sustain. Dev. World Ecol. 2020, 27, 469-480. [CrossRef]

8. Dreher, A. Does globalization affect growth? Evidence from a new index of globalization. Appl. Econ. 2006, 38, 1091-1110. [CrossRef]

9. Gygli, S.; Haelg, F.; Potrafke, N.; Sturm, J.-E. The KOF Globalisation Index-revisited. Rev. Int. Organ. 2019, 14, 543-574. [CrossRef]

10. Rahman, M.M. Environmental degradation: The role of electricity consumption, economic growth, and globalization. J. Environ. Manag. 2020, 253, 109742. [CrossRef]

11. Villanthenkodath, M.A.; Ansari, M.A.; Shahbaz, M.; Vo, X.V. Do tourism development and structural change promote environmental quality? Evidence from India. Environ. Dev. Sustain. 2021, 4, 1-32. [CrossRef]

12. He, X.; Adebayo, T.S.; Kirikkaleli, D.; Umar, M. Consumption-based carbon emissions in Mexico: An analysis using the dual adjustment approach. Sustain. Prod. Consum. 2021, 27, 947-957. [CrossRef]

13. Pata, U.K. Linking renewable energy, globalization, agriculture, $\mathrm{CO}_{2}$ emissions and ecological footprint in BRIC countries: A sustainability perspective. Renew. Energy 2021, 173, 197-208. [CrossRef]

14. Kihombo, S.; Ahmed, Z.; Chen, S.; Adebayo, T.S.; Kirikkaleli, D. Linking financial development, economic growth, and ecological footprint: What is the role of technological innovation? Environ. Sci. Pollut. Res. 2021, 1-11. [CrossRef]

15. Kirikkaleli, D.; Adebayo, T.S.; Khan, Z.; Ali, S. Does globalization matter for an ecological footprint in Turkey? Evidence from dual adjustment approach. Environ. Sci. Pollut. Res. 2021, 28, 14009-14017. [CrossRef] [PubMed]

16. Tufail, M.; Song, L.; Adebayo, T.S.; Kirikkaleli, D.; Khan, S. Do fiscal decentralization and natural resources rent curb carbon emissions? Evidence from developed countries. Environ. Sci. Pollut. Res. 2021, 1-12. [CrossRef]

17. Baloch, M.A.; Danish Qiu, Y. Does energy innovation play a role in achieving sustainable development goals in BRICS countries? Environ. Technol. 2021, 2,1-10. [CrossRef]

18. Oluwajana, D.; Adeshola, I.; Kirikkaleli, D.; Akinsola, G.D.; Adebayo, T.S.; Osemeahon, O.S. Coal Consumption and Environmental Sustainability in South Africa: The role of Financial Development and Globalization. Int. J. Renew. Energy Dev. 2021, 10, $527-536$.

19. Xu, Z.; Baloch, M.A.; Danish Meng, F.; Zhang, J.; Mahmood, Z. Nexus between financial development and $\mathrm{CO}_{2}$ emissions in Saudi Arabia: Analyzing the role of globalization. Environ. Sci. Pollut Res. 2018, 25, 28378-28390. [CrossRef]

20. Salahuddin, M.; Alam, K.; Ozturk, I.; Sohag, K. The effects of electricity consumption, economic growth, financial development and foreign direct investment on $\mathrm{CO}_{2}$ emissions in Kuwait. Renew. Sustain. Energy Rev. 2018, 81, 2002-2010. [CrossRef]

21. Chebbi, H.E. Long and Short-Run Linkages between Economic Growth, Energy Consumption and $\mathrm{CO}_{2}$ Emissions in Tunisia. Middle East Dev. J. 2010, 2, 139-158. [CrossRef]

22. Salahuddin, M.; Gow, J. Economic growth, energy consumption and $\mathrm{CO}_{2}$ emissions in Gulf Cooperation Council countries. Energy 2014, 73, 44-58. [CrossRef]

23. Nain, M.Z.; Ahmad, W.; Kamaiah, B. Economic growth, energy consumption and $\mathrm{CO}_{2}$ emissions in India: A disaggregated causal analysis. Int. J. Sustain. Energy 2017, 36, 807-824. [CrossRef]

24. Wang, S.; Li, Q.; Fang, C.; Zhou, C. The relationship between economic growth, energy consumption, and $\mathrm{CO}_{2}$ emissions: Empirical evidence from China. Sci. Total Environ. 2016, 542, 360-371. [CrossRef]

25. Salari, M.; Javid, R.J.; Noghanibehambari, H. The nexus between $\mathrm{CO}_{2}$ emissions, energy consumption, and economic growth in the U.S. Econ. Anal. Policy 2021, 69, 182-194. [CrossRef]

26. Abbasi, K.R.; Lv, K.; Radulescu, M.; Shaikh, P.A. Economic complexity, tourism, energy prices, and environmental degradation in the top economic complexity countries: Fresh panel evidence. Environ. Sci. Pollut. Res. 2021, 1-15. [CrossRef]

27. Xu, X.; Huo, H.; Liu, J.; Shan, Y.; Li, Y.; Zheng, H.; Guan, D.; Ouyang, Z. Patterns of $\mathrm{CO}_{2}$ emissions in 18 central Chinese cities from 2000 to 2014. J. Clean. Produc. 2018, 172, 529-540. [CrossRef]

28. Su, Z.-W.; Umar, M.; Kirikkaleli, D.; Adebayo, T.S. Role of political risk to achieve carbon neutrality: Evidence from Brazil. J. Environ. Manag. 2021, 298, 113463. [CrossRef] [PubMed]

29. Acheampong, A.O.; Adams, S.; Boateng, E. Do globalization and renewable energy contribute to carbon emissions mitigation in Sub-Saharan Africa? Sci. Total Environ. 2019, 677, 436-446. [CrossRef] [PubMed] 
30. Ayobamiji, A.A.; Kalmaz, D.B. Reinvestigating the determinants of environmental degradation in Nigeria. Int. J. Econ. Policy Emerg. Econ. 2020, 13, 52-71. [CrossRef]

31. Shoaib, H.M.; Rafique, M.Z.; Nadeem, A.M.; Huang, S. Impact of financial development on $\mathrm{CO}_{2}$ emissions: A comparative analysis of developing countries (D8) and developed countries (G8). Environ. Sci. Pollut. Res. 2020, 27, 12461-12475. [CrossRef] [PubMed]

32. Khan, M.S.; Butt, U.U. Asymmetric Impact of Globalization on Economic Growth in Pakistan by Using ARDI Model [Internet]; Report No.: ID 3860498; Social Science Research Network: Rochester, NY, USA, 2021; Available online: https: / / papers.ssrn.com/abstract=38 60498 (accessed on 9 August 2021).

33. Shen, Y.; Su, Z.-W.; Malik, M.Y.; Umar, M.; Khan, Z.; Khan, M. Does green investment, financial development and natural resources rent limit carbon emissions? A provincial panel analysis of China. Sci. Total Environ. 2021, 755, 142538. [CrossRef] [PubMed]

34. Bekhet, H.A.; Matar, A.; Yasmin, T. $\mathrm{CO}_{2}$ emissions, energy consumption, economic growth, and financial development in GCC countries: Dynamic simultaneous equation models. Renew. Sustain. Energy Rev. 2017, 70, 117-132. [CrossRef]

35. Katircioglu, S.; Gokmenoglu, K.K.; Eren, B.M. Testing the role of tourism development in ecological footprint quality: Evidence from top 10 tourist destinations. Env. Sci Pollut Res. 2018, 25, 33611-33619. [CrossRef]

36. Odugbesan, J.A.; Adebayo, T.S.; Akinsola, G.D.; Olanrewaju, V.O. Determinants of Environmental Degradation in Thailand: Empirical Evidence from ARDL and Wavelet Coherence Approaches. Pollution 2021, 7, 181-196.

37. Ahmed, Z.; Nathaniel, S.P.; Shahbaz, M. The criticality of information and communication technology and human capital in environmental sustainability: Evidence from Latin American and Caribbean countries. J. Clean. Prod. 2021, 286, 125529. [CrossRef]

38. Leal, P.H.; Marques, A.C. The environmental impacts of globalisation and corruption: Evidence from a set of African countries. Environ. Sci. Policy 2021, 115, 116-124. [CrossRef]

39. Yuping, L.; Ramzan, M.; Xincheng, L.; Murshed, M.; Awosusi, A.A.; BAH, S.I.; Adebayo, T.S. Determinants of carbon emissions in Argentina: The roles of renewable energy consumption and globalization. Energy Rep. 2021, 7, 4747-4760. [CrossRef]

40. Chen, Y.; Wang, Z.; Zhong, Z. $\mathrm{CO}_{2}$ emissions, economic growth, renewable and non-renewable energy production and foreign trade in China. Renew. Energy 2019, 131, 208-216. [CrossRef]

41. Zhang, J.; Patwary, A.K.; Sun, H.; Raza, M.; Taghizadeh-Hesary, F.; Iram, R. Measuring energy and environmental efficiency interactions towards $\mathrm{CO}_{2}$ emissions reduction without slowing economic growth in central and western Europe. J. Environ. Manag. 2021, 279, 111704. [CrossRef] [PubMed]

42. Piłatowska, M.; Geise, A.; Włodarczyk, A. The Effect of Renewable and Nuclear Energy Consumption on Decoupling Economic Growth from $\mathrm{CO}_{2}$ Emissions in Spain. Energies 2020, 13, 2124. [CrossRef]

43. Khan, Z.; Ali, S.; Umar, M.; Kirikkaleli, D.; Jiao, Z. Consumption-based carbon emissions and International trade in G7 countries: The role of Environmental innovation and Renewable energy. Sci. Total Environment. 2020, 730, 138945. [CrossRef]

44. Adebayo, T.S.; Rjoub, H.; Akinsola, G.D.; Oladipupo, S.D. The asymmetric effects of renewable energy consumption and trade openness on carbon emissions in Sweden: New evidence from quantile-on-quantile regression approach. Environ. Sci. Pollut. Res. 2021, 1-12. [CrossRef]

45. Kirikkaleli, D.; Adebayo, T.S. Do public-private partnerships in energy and renewable energy consumption matter for consumption-based carbon dioxide emissions in India? Environ. Sci. Pollut. Res. 2021, 28, 30139-30152. [CrossRef]

46. Grossman, G.M.; Krueger, A.B. Environmental Impacts of a North American Free Trade Agreement [Internet]; (Papers). Report No.: 158; Woodrow Wilson School-Public and International Affairs: Princeton, NJ, USA, 1991; Available online: https://ideas.repec.org/p/ $\mathrm{fth} / \mathrm{priwpu} / 158 . \mathrm{html}$ (accessed on 24 July 2021).

47. Alibašić, H. Examining the Intersection of Sustainability and Resilience. In Sustainability and Resilience Planning for Local Governments: The Quadruple Bottom Line Strategy [Internet]; Alibašić, H., Ed.; Springer International Publishing: Cham, Switzerland, 2018; Sustainable Development Goals Series. [CrossRef]

48. Akinsola, G.D.; Adebayo, T.S.; Kirikkaleli, D.; Bekun, F.V.; Umarbeyli, S.; Osemeahon, O.S. Economic performance of Indonesia amidst $\mathrm{CO}_{2}$ emissions and agriculture: A time series analysis. Environ. Sci. Pollut. Res. 2021, 1-15. [CrossRef]

49. Adebayo, T.S. Revisiting the EKC hypothesis in an emerging market: An application of ARDL-based bounds and wavelet coherence approaches. SN Appl Sci. 2020, 2, 1945. [CrossRef]

50. Adebayo, T.S.; Kirikkaleli, D. Impact of renewable energy consumption, globalization, and technological innovation on environmental degradation in Japan: Application of wavelet tools. Environ. Dev. Sustain. 2021, 1-26. [CrossRef]

51. Pesaran, M.H. Estimation and Inference in Large Heterogeneous Panels with a Multifactor Error Structure. Econometrica 2006, 74, 967-1012. [CrossRef]

52. Hashem Pesaran, M.; Yamagata, T. Testing slope homogeneity in large panels. J. Econom. 2008, 142, 50-93. [CrossRef]

53. Westerlund, J. Testing for Error Correction in Panel Data*. Oxf. Bull. Econ. Stat. 2007, 69, 709-748. [CrossRef]

54. Chudik, A.; Pesaran, M.H. Common correlated effects estimation of heterogeneous dynamic panel data models with weakly exogenous regressors. J. Econom. 2015, 188, 393-420. [CrossRef]

55. Zhang, L.; Li, Z.; Kirikkaleli, D.; Adebayo, T.S.; Adeshola, I.; Akinsola, G.D. Modeling $\mathrm{CO}_{2}$ emissions in Malaysia: An application of Maki cointegration and wavelet coherence tests. Environ. Sci. Pollut. Res. 2021, 28, 26030-26044. [CrossRef] [PubMed]

56. Ramzan, M.; Adebayo, T.S.; Iqbal, H.A.; Awosusi, A.A.; Akinsola, G.D. The environmental sustainability effects of financial development and urbanization in Latin American countries. Environ Sci Pollut Res 2021, 1-14. [CrossRef] 
57. Udemba, E.N.; Adebayo, T.S.; Ahmed, Z.; Kirikkaleli, D. Determinants of consumption-based carbon emissions in Chile: An application of non-linear ARDL. Environ. Sci. Pollut. Res. 2021, 1-15. [CrossRef]

58. Khan, Z.; Hussain, M.; Shahbaz, M.; Yang, S.; Jiao, Z. Natural resource abundance, technological innovation, and human capital nexus with financial development: A case study of China. Resour. Policy 2020, 65, 101585. [CrossRef]

59. Koengkan, M.; Fuinhas, J.A. Exploring the effect of the renewable energy transition on $\mathrm{CO}_{2}$ emissions of Latin American \& Caribbean countries. Int. J. Sustain. Energy 2020, 39, 515-538.

60. Zaidi, S.A.H.; Zafar, M.W.; Shahbaz, M.; Hou, F. Dynamic linkages between globalization, financial development and carbon emissions: Evidence from Asia Pacific Economic Cooperation countries. J. Clean. Prod. 2019, 228, 533-543. [CrossRef]

61. Usman, O.; Iortile, I.B.; Ike, G.N. Enhancing sustainable electricity consumption in a large ecological reserve-based country: The role of democracy, ecological footprint, economic growth, and globalisation in Brazil. Env. Sci Pollut Res. 2020, 27, 13370-13383. [CrossRef]

62. Usman, O.; Akadiri, S.S.; Adeshola, I. Role of renewable energy and globalization on ecological footprint in the USA: Implications for environmental sustainability. Environ. Sci. Pollut. Res. Int. 2020, 27, 30681-30693. [CrossRef] [PubMed]

63. Adebayo TS, Acheampong AO. Modelling the globalization- $\mathrm{CO}_{2}$ emission nexus in Australia: Evidence from quantile-on-quantile approach. Environ. Sci. Pollut. Res. 2021, 10, 11-26. 